DOI 10.31558/2307-2318.2021.3.15

УДК 331.526-053.81:332.122

JEL: J48, R23

Збрицька Т.П.

кандидат економічних наук, доцент кафедри управління персоналом і економіки праці, Одеський національний економічний університет, Україна

ORCID: 0000-0002-3558-1795

s.t.p._@ukr.net

Мінін B.C.

аспірант кафедри управління персоналом і економіки праці,

Одеський національний економічний університет, Україна

ORCID: 0000-0001-6928-0766

vlad.under.minin97@gmail.com;

\title{
СОЦІАЛЬНО-ЕКОНОМІЧНА ЕФЕКТИВНІСТЬ ЗАЙНЯТОСТІ МОЛОДІ: РЕГІОНАЛЬНИЙ АСПЕКТ
}

В статті зроблено теоретичний огляд системи відносин зайнятості населення та молодіжної зайнятості відповідно до сучасного етапу розвитку економіки країни та регіонів зокрема. Розглянуто компоненти системи відносин зайнятості та групи передумов, що визначають соціально-економічне середовище для нормального функціонування регіонального ринку праці. Зайнятість населення обумовлює соціальноекономічний розвиток регіону, а одним із найважливіших його факторів $\epsilon$ формування інноваційної структури зайнятості, особливо в молодіжному сегменті ринку праці. Розглянуто вплив на зайнятість і потребу в робочій силі зарубіжних науковців. В статті наведено Модель реалізації молодіжної політики в умовах децентралізації та питання молодіжної політики в пріоритетах Державної стратегії регіонального розвитку до 20202027 pp. Існує потреба у комплексному аналізі та прогнозуванні визначених закономірностей на майбутнє за допомогою новітніх теоретико-методичних підходів, що можуть бути використані органами державного управління для розроблення дієвих управлінських рішень у сфері розвитку соціально-трудових відносин на національному/регіональному молодіжному ринку праці.

Ключові слова: зайнятість населення, молодіжний ринок праці, соціальноекономічна ефективність зайнятості, регіональний аспект зайнятості.

Рис. - 3, Табл. - 1, Літ. - 9.

Постановка проблеми. Структура зайнятості населення свідчить не тільки про рівень зайнятих, класифікованих за різними ознаками, але й про весь соціальноекономічний розвиток країни, регіону та галузі. Проблеми структурних змін зайнятості населення у розрізі окремого регіону за ступенем соціально-економічного розвитку самого регіону України досить диференційовані. Подолання диспропорцій у структурі зайнятості населення регіону та забезпечення умов іiі збалансованого соціальноорієнтованого розвитку вимагає застосування нових заходів, підходів та побудови ефективних механізмів трансформації зайнятості населення та зокрема молоді. 
Аналіз останніх досліджень і публікацій. Проблемам зайнятості присвячено великий обсяг праць сучасних вітчизняних та зарубіжних учених-економістів: В. Брич, О. Грішнова; А. Колот; Т. Заяць, О. Левченко, Е. Лібанова, Л. Лісогор, В. Нижник, М. Семикіна, Л. Шаульська, Фільштейн та ін. Проблеми зайнятості населення відображені у працях зарубіжних учених: А. Сміта, К. Маркса, Дж. Кейнса, Ф. Кене, А. Маршала, А. Оукена, П.Самуельсона тощо.

Проблеми молодіжного сегменту забезпечення й ефективної зайнятості досліджено у багатьох роботах науковців. Серед українських вчених ці питання висвітлені у дослідженнях: Д. Богині; І. Бондар; М. Долішнєго; О. Дороніної; О. Дяків; Н. Лук'янченко; В. Онікієнка; О. Яременко та інших. Різні аспекти формування та розвитку молодіжного ринку праці викладено у роботах й зарубіжних науковців, як: Р. Джекман; Р. Леярд; К. Маккен; Д. Мортенсен; Т. Парсонс; Т. Роззак; Г. Стенлі; Р. Філер, та інші.

Незважаючи на достатню кількість наукових публікацій з питань державного регулювання молодіжного ринку праці, у сучасній літературі недостатньо уваги приділено комплексності та практичній спрямованості заходів щодо забезпечення й ефективної зайнятості молоді, усунення дисбалансу між попитом і пропозицією робочої сили на молодіжному ринку праці.

Формулювання цілей статті. Метою статті $є$ теоретичний огляд системи відносин зайнятості населення та молодіжної зайнятості відповідно до сучасного етапу розвитку економіки країни та регіонів зокрема. Дослідження сутності соціально-економічної ефективності зайнятості молоді, іiі забезпечення, регулювання та переосмислення $\epsilon$ важливим аспектом для оцінки стану як державного так і регіонального ринку праці.

Виклад основного матеріалу. Ефективне функціонування ринкової економіки неможливе без розвиненого ринку праці, адже ринок праці $є$ необхідною ланкою у всьому ланцюгу макроекономічного процесу, дієвим механізмом узгодження економічних інтересів його суб'єктів. Водночас неналежне функціонування ринку праці може породжувати ряд проблем - бідність, безробіття, інфляцію, соціальну напруженість у суспільстві (мітинги, демонстрації, страйки) тощо [1].

Ситуація на ринку праці регіону поки що далека від стабілізації, питання про активізацію державного регулювання ринку праці та зміни деяких уявлень про те, хто і як має здійснювати таке регулювання, поставлене досить гостро.

Регулювання ринку праці на регіональному рівні набуває, сьогодні, особливого значення, так як лише на рівні регіону можуть бути найбільш повно враховані їх соціально-економічні, демографічні, екологічні та інші особливості. Зайнятість необхідно розглядати як систему відносин, що виникають в межах суб'єктних структурних складових, рис. 1 [2].

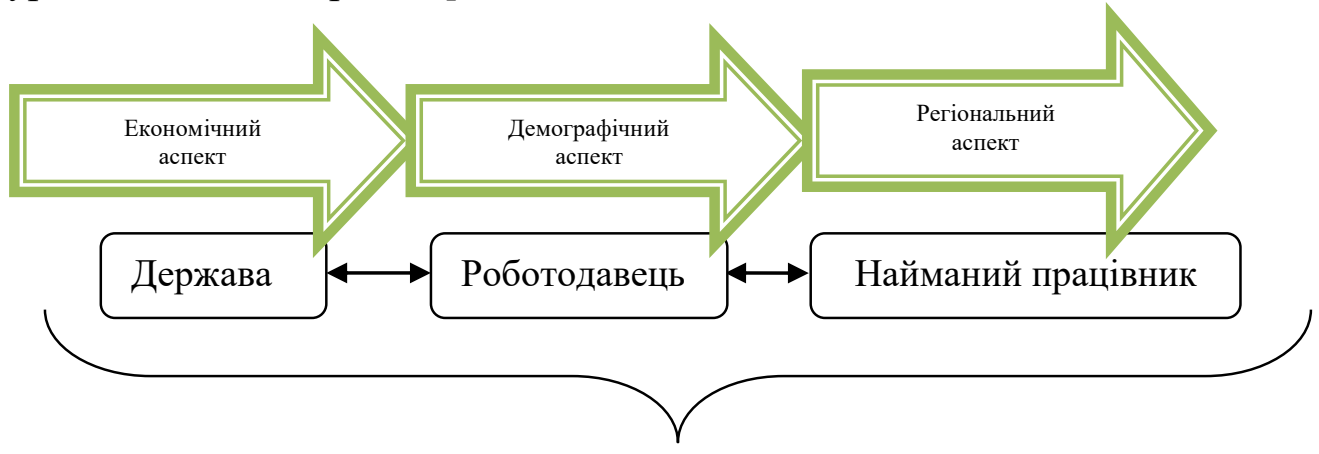

Система відносин зайнятості

Рисунок 1. Компоненти системи відносин зайнятості 
Відповідно до запропонованого підходу зайнятість населення як система відносин в рамках суб'єктної складової і в цілому охоплює економічні, правові, соціальні, національні та регіональні відносини.

У свою чергу, В.В Близнюк виділяє чотири групи передумов, що визначають соціально-економічне середовище для нормального функціонування регіонального ринку праці [3]:

1) правові - визначають соціально-економічну компетенцію та юридичний статус органів місцевого самоврядування стосовно управління трудовими ресурсами. Вони обумовлюють правове середовище формування соціального партнерства в регіоні;

2) економічні, що обумовлюють сукупність базових ресурсів в регіоні, а також необхідність узгодженості їх використання задля зростання зайнятості;

3) соціальні - передбачають формування системи захисту працездатного населення;

4) організаційні, які визначають інфраструктурні можливості розвитку та зростання зайнятості.

Зважаючи на те, що належність працездатного населення до складу робочої сили та його активність на ринку праці безпосередньо впливають на рівень доходів населення регіону, а отже й визначають рівень життя, економічна активність та рівень життя населення мають бути у сучасних умовах пріоритетними об'єктами соціальноекономічного управління, до якого 3 дотриманням принципу солідарності, свідомо та активно залучаються представники всіх сторін соціально-трудових відносин. У той же час, фактичний рівень та динаміка зазначених показників можуть розглядатися у якості взаємопов'язаних індикаторів стану соціально-трудових відносин, оскільки взаємовідносин між їхніми сторонами, органами сторін за участі держави та місцевого самоврядування безпосередньо мають бути орієнтовані на ефективну зайнятість (через зростання економічної активності населення) та підвищення рівня життя тощо.

Структурні зрушення економіки, що відбуваються як в цілому в країні, так і в їі регіонах, призводять до трансформації національного та регіонального ринків праці, кардинальних змін у структурі зайнятості населення. Зайнятість населення обумовлює соціально-економічний розвиток регіону, а одним із найважливіших його факторів $\epsilon$ формування інноваційної структури зайнятості, особливо в молодіжному сегменті ринку праці.

Людство в XXI столітті зіткнулося із загостренням соціально-економічних проблем молоді. Фінансова криза, яка переросла в соціально-економічну, призвела до різкого зростання безробіття серед молоді як у всьому світі, так і в Україні, і посилила недовіру молодих людей до уряду.

Визначення сутності зайнятості та факторів впливу дозволяє конкретизувати елементи механізму регулювання зайнятості та ринку праці. Так, ефективна зайнятість $€$ складним поняттям і передбачає використання персоналу з мінімальними втратами робочого часу, коли досягається найбільший економічний результат. Під ефективною зайнятістю молоді слід розуміти такий стан ринку праці, коли досягається збалансованість інтересів молодих фахівців, роботодавців та держави. За таких умов економіка досягає максимальних результатів соціально-економічного розвитку при найменших питомих витратах ресурсів із забезпеченням рівномірного та пропорційного територіального, міжгалузевого та професійно-кваліфікаційного підходу.

В реальній економіці, навіть, високо розвинуті країни світу не досягають балансу інтересів між різними заінтересованими сторонами, оскільки на зайнятість населення впливають різноманітні фактори. Тому державна політика у цій сфері повинна бути 
спрямована не лише на забезпечення зайнятості, а й на стимулювання ефективної зайнятості.

Проблема молодіжної зайнятості має об’єктивний характер. В умовах вільної конкуренції на ринку праці через відсутність необхідного досвіду роботи та й просто життєвого досвіду молода особа часто не може на рівних конкурувати з досвідченими фахівцями.

Соціологічні дослідження свідчать, що нині існує відчутна нерівність серед молоді у можливостях набуття загальної освіти, духовного і культурного розвитку, професійної підготовки, виборі місця праці. Причин цих явищ є багато: це і соціальні наслідки демографічних, організаційних, структурних диспропорцій в межах цілої країни, які утворювались історично і поглиблювались в умовах економічної кризи, і зростання соціальної нерівності в усьому суспільстві, що особливо позначається на молоді, i відсутність сильної державної соціальної політики, тощо. Наприклад, у порівнянні 3 міською молодцю у сільських хлопців та дівчат невисокі можливості набуття якісної освіти, престижних місць працевлаштування, змістовного проведення дозвілля. Все це спричиняє помітне зменшення питомої ваги молоді у складі сільського населення, iіi масове переміщення у міста і перетворення сільської молоді в них на маргінальний (від лат. marginalis - той, що знаходиться на краю, на узбіччі) прошарок.

Разом 3 тим за сучасних реалій у структурі зайнятості населення в різних регіонах України відбуваються негативні зрушення, що мають руйнівний вплив на розвиток національної економіки й полягають у дисбалансі попиту та пропозиції робочої сили, зростанні масштабів незайнятості, неврегульованості нестандартних форм зайнятості та слабкій соціальній захищеності працівників. За таких обставин з особливою гостротою постає проблема здійснення активних заходів регулювання структурних змін зайнятості населення, актуальність якої зростає в сучасних умовах, коли в Україні склалася вкрай складна і напружена ситуація в соціально-економічній сфері через системну кризу.

Економічний спад та політична конфліктність в суспільстві провокують додаткове навантаження на ринки праці майже всіх регіонів, зростання чисельності безробітних. Дослідження структурних змін зайнятості населення за нинішніх реалій соціальноекономічного розвитку України $\epsilon$ надзвичайно актуальним, тому що зайнятість $\epsilon$ основою для відтворення трудового потенціалу, а запровадження активних заходів державного механізму регулювання й розширення зайнятості сприятиме скороченню рівня таких негативних соціально-економічних наслідків, як безробіття та бідність.

Однак, незважаючи на вагомі здобутки дослідників проблем ринку праці i зайнятості, слід констатувати, що кожному регіону притаманна своя специфіка, яка зумовлює потребу комплексного підходу до цих питань, зокрема необхідність розробки прикладних рекомендацій щодо регулювання змін у структурі зайнятості населення 3 урахуванням процесів євроінтеграції, руху до інноваційної економіки.

Для всіх країн світу зайнятість населення посідає провідне місце у системі соціальних та економічних проблем і разом 3 показниками рівня життя $є$ важливим індикатором соціальних процесів. Перехід від планово-централізованого до вільного руху трудових ресурсів змінює систему інтересів, мотивів і стимулів діяльності економічно активного населення, що, відповідно, впливає на джерела наповнення ринку праці, сегментацію та напрями державного регулювання зайнятості населення [4].

Для західної соціології молодіжні проблеми набувають дещо іншої пріоритетності та змісту. Центральною з них вважається напруження між молоддю та суспільством, яке робить можливим конфлікт між індивідуальностями та існуючим соціальним устроєм. В основі цього напруження лежить амбівалентність (тобто двоїстість, суперечливість 
почуттів та емоцій) молоді, яка здатна привести i до політичного активізму, і до інтенсивної само-трансформації особистості, і до іiі втечі у світ наркотиків або релігії. Тому одним із завдань молодіжної політики у розвинутих країнах є створення таких умов для молоді, коли б ця амбівалентність якомога лагідніше скеровувалась у просоціальному напрямку через надання найрізноманітніших можливостей для соціально корисної діяльності молоді як на рівні держави та регіонів зокрема. Так, досліджуючи вплив на зайнятість і потребу в робочій силі зарубіжні науковці беруть до уваги такі важливі чинники як [4]:

- особливості територіальної (регіональної) організації економіки та соціальних структур;

- $\quad$ сукупність кадрів з певним рівнем кваліфікації та підготовки на даний момент часу;

- потребу, дефіцит або навпаки - надмірну кількість трудових ресурсів за певної ситуації на ринку;

- $\quad$ внутрішні критерії (рівень життя, праці), а також специфічні чинники: структурну перебудову, демонополізацію господарського комплексу;

- рівень збалансованості економіки;

- конверсію;

- рівень кооперації з іншими країнами;

- рівень продуктивності та оплати праці;

- зміну форми власності;

- розвиток приватизації та рівень соціального захисту безробітних;

- $\quad$ рівень державного регулювання та управління ринком праці.

Вітчизняний науковець, О.В. Швець в цьому зв'язку зазначає, що вагомими передумовами економічного i соціального розвитку $\epsilon$ взаємозв'язок структурноінституціональних змін у господарському комплексі регіону в аспекті зайнятості, міжнародної трудової міграції та економічної безпеки [5].

Для дослідження структури зайнятості регіону доцільно використати системний підхід, на основі якого виокремити такі напрями аналізу: територіально-галузевий розподіл ресурсів праці, робочих місць, робочого часу, використання праці та територіальні відмінності суспільного життя.

Структура зайнятості сформована зрушеннями в певному соціально-економічному середовищі, яке визначається технологічними та інноваційними перетвореннями, регіональними відмінностями зайнятих, їх заробітної плати, рівня життя працюючих, рис. 2 [6].

На думку, науковця Н.П. Казюка, концептуальна модель регулювання структурних змін у зайнятості населення регіону, має особливості які полягають у:

1) модель передбачає регуляторні заходи на ринку праці, що розвивають положення концепції «флексік'юріті» (забезпечення гнучкої зайнятості та соціального захисту);

2) характеризує дію множини факторів, які впливають на сучасний соціальноекономічний та інноваційний розвиток економіки регіонів в Україні, зумовлюючи зміни у структурі зайнятості населення;

3) акцентує увагу на підвищенні ролі служби зайнятості у збалансуванні попиту і пропозиції на регіональному ринку праці [7]. 


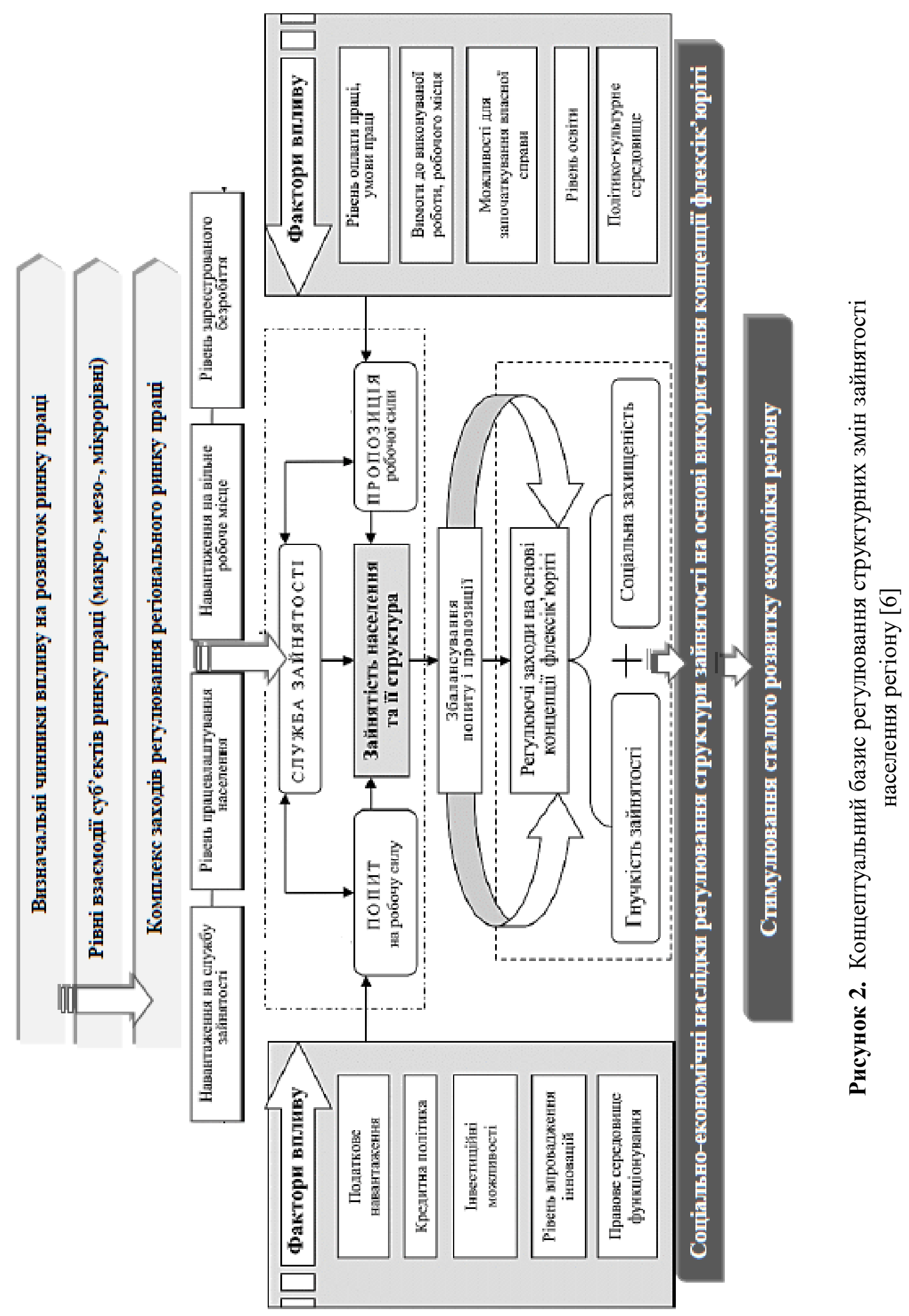


Очевидно, що дослідження факторів формування зайнятості молоді має виняткове значення для розробки заходів щодо підвищення її ефективності як на національному, так і регіональному рівнях. Такий аналіз повинен здійснюватися на основі використання законів, закономірностей і принципів розвитку демографії, економіки праці, економічної науки для розробки в подальшому стратегічних програмних документів стосовно ефективного коригування розвитку системоутворюючих факторів.

Ефективність молодіжної політики в Україні в умовах децентралізації значною мірою залежить лише від єдності та скоординованості дій виконавчої влади, місцевого самоврядування і молодіжного представництва.

Міністерством молоді та спорту разом із представниками державного та громадського секторів, місцевого самоврядування, експертами, молодіжними лідерами розроблено Модель реалізації молодіжної політики в умовах децентралізації, яка була схвалена на засіданні колегії відомства 21 грудня 2017 року та рекомендована до впровадження, рис.3 [8].

Модель формує новий підхід - від «роботи з молоддю» до «молодіжної участі» та грунтується на міжсекторальній взаємодії і враховує територіальні особливості молодіжної роботи відповідно конкретних потреб молоді. На національному рiвні центральним органом виконавчої влади, що забезпечує формування та реалізацію молодіжної політики, є Міністерство молоді та спорту, яке в умовах децентралізації має виконувати такі функції:

- нормативно-правове забезпечення;

- формування стратегії розвитку та пріоритетних напрямів молодіжної політики;

- забезпечення підвищення кваліфікації молодіжних працівників;

- методична підтримка з урахуванням міжнародного досвіду та кращих практик;

- фінансування або сприяння в залученні фінансових коштів на реалізацію програм, проектів тощо.

Регіональний рівень має відповідати за реалізацію молодіжної політики в рамках підходів, запропонованих на національному рівні, зокрема в межах:

- Державної стратегії регіонального розвитку (на сьогодні вже сформована державна та регіональні стратегії соціально-економічного розвитку країни до 2027 року, де наголошено про ключову роль молоді в побудові демократичної України, табл.1 [9]);

- Національної молодіжної стратегії до 2030 року;

- Державної цільової соціальної програми «Молодь України» на 2016 - 2020 рр. (Постанова КМУ від 18 лютого 2016 року № 148) та на 2021-2025 pp. (Постанова КМУ №579 від 2 червня 2021 р.) та Наказу №4334 від 19.09.2018 р. щодо порядку реалізації програми «Молодіжний працівник» (із змінами i доповненнями, внесеними наказом Міністерства молоді та спорту України від 14 серпня 2020 року № 1025).

Окрім цих базових документів була сформована низка Указів та Розпоряджень Президента, які регламентують окремі аспекти державної молодіжної політики, зокрема щодо: підтримки молодіжних громадських організацій, забезпечення працевлаштування, розвиток молодіжного житлового будівництва, робота з обдарованою молоддю тощо. На виконання цих законів та указів періодично формувалися відповідні стратегії, державні та регіональні цільові програми. На своєму рівні можуть бути розроблені та ухвалені регіональні програми, орієнтовані на потреби молоді, з урахуванням місцевих особливостей.

Місцевий рівень характеризується тим, що децентралізація передбачає збільшення відповідальності на місцях, перегляд можливостей для реалізації молодіжної політики на місцевому рівні, відповідно функцій основних гравців. 


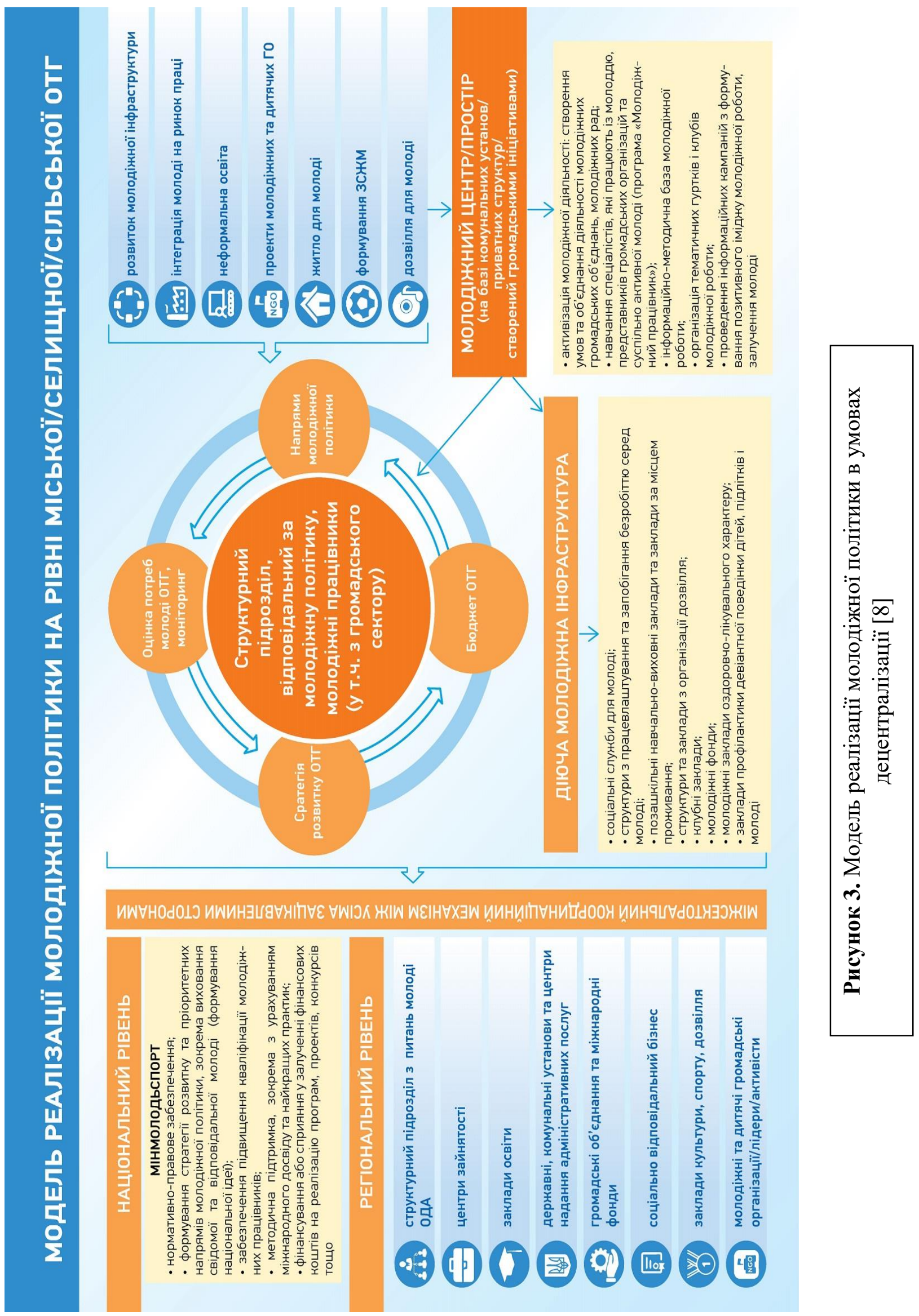


Таблиця 1. Питання молодіжної політики в пріоритетах Державної стратегії регіонального розвитку до 2020-2027 pp.

\begin{tabular}{|c|c|}
\hline \multicolumn{2}{|c|}{$\begin{array}{c}\text { Питання молодіжної політики в пріоритетах Державної стратегії регіонального } \\
\text { розвитку }\end{array}$} \\
\hline до 2020 року & до 2027 року \\
\hline 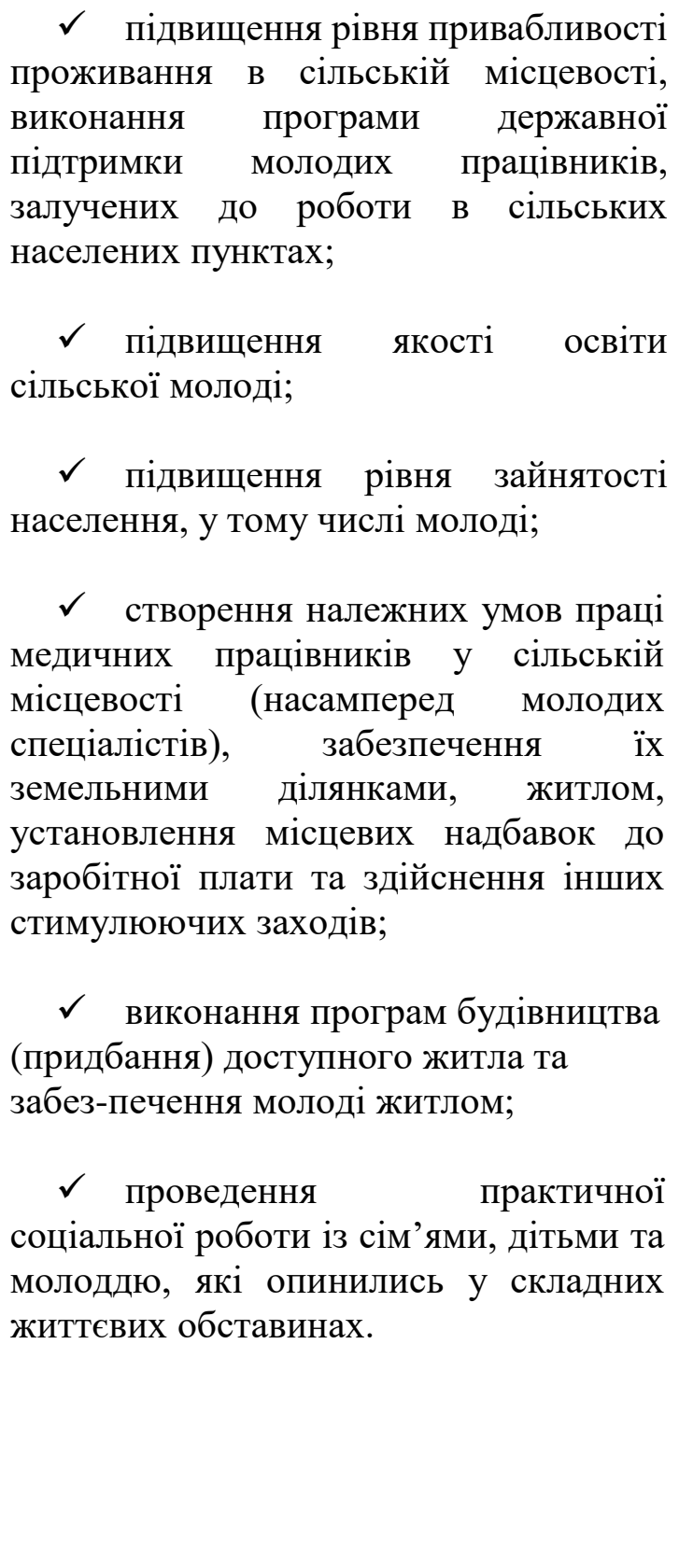 & $\begin{array}{l}\checkmark \text { заохочення молоді до активної } \\
\text { діяльності, розроблення інноваційних } \\
\text { продуктів і започаткування бізнесу у сфері } \\
\text { туризму та курортів за результатами } \\
\text { проведення конкурсів на регіональному } \\
\text { piвні; } \\
\checkmark \text { формування } \\
\text { громадянської (національної) ідентичності, } \\
\text { готовності громадян, особливо дітей та } \\
\text { молоді, брати відповідальність за долю нації } \\
\text { і держави, та мати широкі можливості для } \\
\text { успішної самореалізації в Україні; } \\
\checkmark \text { формування місії позашкільної } \\
\text { освіти як розвитку здібностей дітей та } \\
\text { молоді у сфері освіти, науки, культури, } \\
\text { фізичної культури і спорту, технічної та } \\
\text { іншої творчості, здобуття ними первинних } \\
\text { професійних знань, вмінь і навичок, } \\
\text { необхідних для іх соціалізації, подальшої } \\
\text { самореалізації та/або професійної } \\
\text { діяльності; } \\
\checkmark \text { розвиток підприємницької ініціативи } \\
\text { серед молоді, яка сприятиме упередженню } \\
\text { безробіття в молодіжному середовищі, а } \\
\text { також соціальної напруги в регіоні; } \\
\checkmark \text { розвиток мережі фізкультурно- } \\
\text { оздоровчих і спортивних споруд, } \\
\text { збільшення асигнувань на розвиток фізичної } \\
\text { культури і спорту, зокрема мережі закладів } \\
\text { дитячо-юнацького та резервного спорту, з } \\
\text { метою покращення умов для організації } \\
\text { фізкультурно-спортивної діяльності та } \\
\text { збільшення кількості залучених до занять } \\
\text { спортом, не лише дітей та молоді, а й інших } \\
\text { верств населенняю. }\end{array}$ \\
\hline
\end{tabular}

* Складено автором за [9]

Структурно-функиіональна модель реалізації молодіжної політики на рівні ОТГ, яка зосереджує увагу на тому, що молодіжна політика інтегрує в собі усі інші сфери відповідальності по роботі 3 молоддю: освіту, працевлаштування та ринок праці, культурний розвиток, соціальний захист тощо. 
Для ефективної реалізації молодіжної політики в ОТГ важливо передбачити:

$\checkmark$ необхідну інфраструктуру молодіжної політики, у тому числі їі організаційне та фінансове забезпечення;

$\checkmark$ забезпечення діяльності молодіжних центрів і молодіжних працівників;

$\checkmark$ розвиток інститутів громадянського суспільства;

$\checkmark$ міжгалузеву та міжсекторальну взаємодію у молодіжній роботі;

$\checkmark$ оцінювання ефективності молодіжної роботи і звітування перед громадою про стан роботи з молоддю;

$\checkmark$ забезпечення умов молодіжної участі та молодіжного громадського контролю [8].

Висновки та перспективи подальших досліджень. Оцінювання рівня розвитку економічно активного населення (робочої сили) та функціонування ринку праці регіонів України передбачає проведення комплексного статистичного аналізу його основних показників. Серед ключових напрямів дослідження необхідно виділити аналіз динаміки основних показників економічної активності, що передбачає оцінювання фактичної зміни рівнів, виявлення тенденцій і закономірностей їх розвитку. Поряд із цим існує потреба у прогнозуванні визначених закономірностей на майбутнє за допомогою новітніх теоретико-методичних підходів, використання яких для прогнозування основних показників зайнятості та безробіття населення дасть змогу отримати статистично значимі оцінки досліджуваних процесів на майбутні періоди часу, що можуть бути використані органами державного управління для розроблення дієвих управлінських рішень у сфері розвитку соціально-трудових відносин на національному/регіональному молодіжному ринку праці.

Успішна самореалізація та розвиток молоді в Україні залежать від узгодженості дій багатьох зацікавлених сторін: органів державної влади та органів місцевого самоврядування, громадянського суспільства, бізнесу, родини тощо.

\section{СПИСОК ВИКОРИСТАНИХ ДЖЕРЕЛ}

1. Близнюк В., Яценко Л. Соціальна справедливість у трудовій сфері України: сучасні реалії, проблеми та протиріччя. Стратегічні пріоритети. 2017.№ 4. С. 104-117.

2. Візняк Ю.Я. Регулювання зайнятості населення у прикордонному адміністративному районі: дис. канд. екон. наук.: 08.00.07 / ПВНЗ Львів. ун-т бізнесу та права, Львів. 2012. $235 \mathrm{c}$.

3. Близнюк В.В. Український ринок праці: історичні виклики та нові завдання. Український соціум. 2016. № 3. С. 58-71.

4. Швец А. В. Зависимость сферы занятости населения от стратегической модели развития экономики. Стратегия и тактика развития производственно-хозяйственных систем: Сборник материалов XI Международной научно-практической конференции. (м. Гомель, Беларусь, 21-22 ноября 2019 р.) Гомель: ГГТУ им. П.О. Сухого. с. 84 - 88.

5. Лагодієнко В.В., Швець О.В. Теоретико-методологічні аспекти розвитку регіонального ринку праці. Slovak international scientific journal. № 44.2020. С. 11-14.

6. Швець О.В. Економічна активність населення в умовах трансформації регіонального ринку праці:проблеми та стратегічні пріоритети: дис. док.екон.наук: 08.00.05 - розвиток продуктивних сил і регіональна економіка/ПВНЗ Міжнародний ун-т бізнесу і права. Одеська національна академія харчових технологій. Одеса, 2021.

7. Казюка Н. П. Структурні зміни у зайнятості населення Карпатського регіону та їх регулювання. дис. канд. екон. наук: 08.00.07 / Прикарпат. нац. ун-т ім. В. Стефаника. Івано-Франківськ. 2016. 276 с. 
8. Децентралізація дає можливості/Молодіжна політика в умовах децентралізації. «Модель реалізації молодіжної політики в умовах децентралізації» URL: https://decentralization.gov.ua/youth/molod-v-oth.

9. Софій О. Аналітична записка «Аналіз регіональної молодіжної політики». Громадська організація Європейський діалог, 2020. 63 с.

\section{REFERENCES}

1. Blyzniuk V., Yatsenko L. Social justice in the labor sphere of Ukraine: modern realities, problems and contradictions. Strategic priorities. 2017.№ 4. pp. 104-117.

2. Viznyak Yu.Ya. Regulation of employment in the border administrative area: dis. Cand. econ. Sciences: 08.00.07 / Lviv Higher Educational Institution. University of Business and Law, Lviv. 2012. 235 p.

3. Bliznyuk VV Ukrainian labor market: historical challenges and new challenges. Ukrainian society. 2016. № 3. pp. 58-71.

4. Shvets AV Dependence of employment on the strategic model of economic development. Strategy and tactics of development of production and economic systems: Collection of materials of the XI International scientific and practical conference. (Gomel, Belarus, November 21-22, 2019) Gomel: GSTU. ON. Dry. with. 84 - 88.

5. Lagodienko VV, Shvets OV Theoretical and methodological aspects of the development of the regional labor market. Slovak international scientific journal. № 44.2020. pp. 11-14.

6. Shvets OV Economic activity of the population in the conditions of transformation of the regional labor market: problems and strategic priorities: dis. dok.ekon.nauk: 08.00.05 development of productive forces and regional economy / VVN International University of Business and Law. Odessa National Academy of Food Technologies. Odessa, 2021.

7. Kazyuka NP Structural changes in employment of the Carpathian population region and their regulation. dis. Cand. econ. Science: 08.00.07 / Carpathians. nat. Univ. V. Stefanika. IvanoFrankivsk. 2016. 276 p.

8. Decentralization provides opportunities / Youth policy in a decentralized environment. "Model of youth policy implementation in the context of decentralization" URL: https://decentralization.gov.ua/youth/molod-v-oth.

9. Sofiy O. Analytical note "Analysis of regional youth policy". Non-governmental organization European Dialogue, 2020. 63 p.

Збрицкая Т.П., Минин В.С.

СОЦИАЛЬНО-ЭКОНОМИЧЕСКАЯ ЭФФЕКТИВНОСТЬ ЗАНЯТОСТИ МОЛОДЕЖИ: РЕГИОНАЛЬНЫЙ АСПЕКТ

В статье сделан теоретический обзор системы отношений занятости населения и молодежной занятости в соответствии с современными этапами развития экономики страны и регионов 8 частности. Рассмотрены компоненты системы отношений занятости и группы предпосылок, определяющих сочиально-экономическую среду для нормального функционирования регионального рынка труда. Занятость населения обусловливает сочиально-экономическое развитие региона, а одним из важнейших его факторов является формирование инновационной структуры занятости, особенно в молодежном сегменте рынка труда. Рассмотрено влияние на занятость и потребность в рабочей силе зарубежных ученых. В статье приведень Модель реализачии молодежной политики в условиях децентрализаџии и вопросы молодежной политики в приоритетах Государственной стратегии регионального развития до 2020-2027 г2. Существует потребность в комплексном анализе и прогнозировании определенных закономерностей на будущее с помощью новейших теоретикометодических подходов, которые могут быть использованы органами государственного управления для разработка действенных управленческих решений в сфере развития соииально-трудовых отношений на национальном / региональном молодежном рынке труда. 
Ключевые слова: занятость населения, молодежный рынок труда, социально-экономическая эффективность занятости, региональный аспект занятости.

\section{T. Zbritskaya, V. Minin}

\section{SOCIO-ECONOMIC EFFICIENCY OF YOUTH EMPLOYMENT: A REGIONAL ASPECT}

The article provides a theoretical overview of the system of relations between employment and youth employment in accordance with the current stages of economic development of the country and regions in particular. The components of the system of employment relations and the group of preconditions that determine the socioeconomic environment for the normal functioning of the regional labor market are considered. Employment determines the socio-economic development of the region, and one of its most important factors is the formation of an innovative structure of employment, especially in the youth segment of the labor market. The impact on employment and labor demand of foreign scientists is considered. The article presents the Model of implementation of youth policy in the conditions of decentralization and issues of youth policy in the priorities of the State Strategy of Regional Development until 2020-2027. There is a need for a comprehensive analysis and forecasting of certain patterns for the future using the latest theoretical and methodological approaches that can be used by government to develop effective management decisions in the development of social and labor relations in the national / regional youth labor market.

Keywords: employment, youth labor market, socio-economic efficiency of employment, regional aspect of employment. 